\title{
РОЛЬ ДИСФУНКЦИИ ЭНДОТЕЛИЯ СОСУДОВ В РАЗВИТИИ ОСТЕОПОРОТИЧЕСКИХ ИЗМЕНЕНИЙ КОСТНОЙ ТКАНИ
}

\author{
М.О. Мишенин, О.С. Гудырев \\ ФГАОУ ВО «Белгородский государственный национальный исследовательский \\ университет»
}

DOI: 10.19163/MedChemRussia2021-2021-464

E-mail:gudyrev@bsu.edu.ru

В эксперименте использовались 72 самки крыс линии Wistar массой 200250 г. Остеопороз моделировали путем овариэктомии. Развитие остеопороза оценивали через 8 при помощи ряда методик. Уровень микроциркуляции оценивали в ткани проксимального метафиза бедра (Biopac systems, США: полиграф MP150, модуль LDF100C, датчик TSD144). После оценки микроциркуляции проводили пробы на эндотелийзависимую вазодилатацию (ЭЗВД) в ответ на внутривенное введение 40 мкг/кг ацетилхолина и эндотелийнезависимую вазодилатацию (ЭНВД) в ответ на внутривенное введение 30 мкг/кг нитропруссида натрия. Регистрировали результаты в программе AcqKnowledge, значения выражали в перфузионных единицах (ПЕ). Для подтверждения развития генерализованного остеопороза проводили морфологическое исследование проксимальных метафизов бедренной и плечевой костей, а также тел поясничных позвонков. Гистологические препараты окрашивали гематоксилин-эозином, подвергали световой микроскопии и гистоморфометрии.

Уровень микроциркуляции у интактных крыс ( $n=30)$ составил 100,5 $\pm 4,4$ ПЕ,

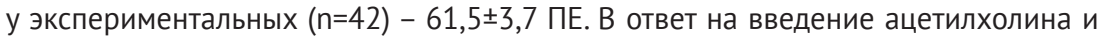
нитропруссида наблюдали снижение микроциркуляции с последующей нормализацией показателей. Рассчитывали коэффициент эндотелиальной дисфункции (КЭД) как отношение площади треугольника реакции ЭНВД к площади треугольника реакции ЭЗВД. В группе интактных животных КЭД=1,3 00,2, в группе экспериментальных животных КЭД=2,4士0,2. Остеопоротические изменения были гистологически подтверждены у всех крыс экспериментальной группы: наблюдалось истончение и микропереломы трабекул. Мерой оценки развития остеопороза стало уменьшение ширины трабекул. Средняя ширина трабекул у крыс с остеопорозом в метафизе бедра была меньше показателя интактных животных на $36,8 \%$; в метафизе плеча - на 37,8\%; в телах поясничных позвонков - на 43,7\%. Коэффициент корреляции Пирсона (r) между микроциркуляцией и шириной трабекул в группе интактных животных $r=0,7$, в группе крыс с остеопорозом $r=0,6$. Таким образом, после овариэктомии у крыс развивается эндотелиальная дисфункция, отмечается значительное ухудшение кровотока в костной ткани, приводящее к дисбалансу процессов костного ремоделирования и развитию остеопороза. Подтверждением служит наличие прямой зависимости между уровнем микроциркуляции в кости проксимального метафиза бедра и шириной костных трабекул в данной локализации у крыс. 